\title{
Frequent Low Level Expression in Ewing Sarcoma Family Tumors and Widespread Absence of the Metastasis Suppressor KAI1/CD82 in Neuroblastoma
}

\author{
DAVE N.T. ARYEE, INGE AMBROS, PETER F. AMBROS, KARIN MUEHLBACHER, \\ ANDREA LUEGMAYR, OSAMU YOSHIE, AND HEINRICH KOVAR
}

Children's Cancer Research Institute (CCRI), St. Anna Kinderspital, A-1090 Vienna, Austria [D.N.T.A., I.A., P.F.A., K.M., A.L., H.K.], and Kinki University School of Medicine, Department of Bacteriology, Osaka-Sayama, Japan [O.Y.]

\begin{abstract}
The transmembrane 4 superfamily member KAI1/CD82, a metastasis suppressor, is correlated inversely with the progression and invasion of several tumors. It is capable of inhibiting metastasis without affecting tumorigenicity per se. KAI1/CD82 expression is down-regulated in the progression of common solid epithelial tumors of adulthood. Mutation of p53 is suggested to be involved in the modulation of KAI1. As little is known about its expression and possible prognostic impact in pediatric tumors, we investigated KAI1/CD82 expression in cell lines and primary tumor samples from pediatric tumors of neuroectodermal origin, neuroblastoma and Ewing's sarcoma family tumor. Twenty-four of 29 Ewing's sarcoma family tumor cell lines, independent of p53 status, showed KAII mRNA positivity by reverse transcription-PCR analysis in contrast to zero of eight neuroblastoma cell lines. Among 13 primary Ewing's sarcoma family tumor samples from patients with different disease extension, KAII mRNA expression was low as detected by reverse transcription-PCR.
\end{abstract}

\section{ABSTRACT}

Twenty of 30 primary neuroblastoma specimens were KAIInegative by immunofluorescence analysis whereas the remaining 10 gave weak to moderate staining patterns. There was no apparent correlation of KAII expression with any clinical or genetic features of the patients whose tumor samples were studied. Consequently, KAII may not be of prognostic relevance in this group of tumors although there may be some role for KAII modulation in the biology of these neuroectodermal tumors.

(Pediatr Res 52: 279-285, 2002)

$\quad$ Abbreviations
EFT, Ewing sarcoma family tumors
NB, neuroblastoma
RT-PCR, reverse transcription-PCR
SSCP, single-strand conformational polymorphism
TM4SF, transmembrane 4 superfamily

A major challenge in oncology is to predict metastatic potential of tumor cells. The genetic events controlling metastasis are presently poorly understood (1). Metastasis suppressor genes, which are functionally inactivated as tumor cells acquire metastatic ability, may have significant prognostic value. Several metastasis suppressor genes have been mapped, but only few cloned to date $(2,3)$. KAI1 protein is a member of the TM4SF (4), which are cell membrane proteins. Many of the TM4SF members, including KAI1, are CD antigens present on the surface of leukocytes (5), and KAI1 is designated CD82 by the clusters of differentiation (CD) nomenclature (6). At least three members of

Received October 15, 2001; accepted March 1, 2002.

Correspondence and reprint requests: Dave N.T. Aryee, Ph.D., Children's Cancer Research Institute (CCRI), St. Anna Kinderspital, Kinderspitalgasse 6, A-1090 Vienna, Austria; e-mail: aryee@ccri.univie.ac.at

Supported mainly by private donations to the CCRI.

DOI: 10.1023/01.PDR.0000019120.48685.02 the TM4SF family have been implicated in metastasis, including CD9/MRP-1, (7) CD63/ME491 (8), and KAI1/CD82 (9). KAI1 (CD82) contains three potential N-linked glycosylation sites and is a glycoprotein (9-12). KAI1 and other TM4SF members have been shown to bind to each other $(5)$, integrins $(13,14)$, and E-cadherin (15). Physical association with other molecules has been reported for several TM4SF members $(16,17)$, which may underline a mechanism for their diversity of function.

$K A I 1$ mRNA is ubiquitously expressed, with abundant levels in the surface of the major epithelial tissues, including lung, breast, prostate, and the gastrointestinal tract $(18,19)$. The physiologic roles of TM4SF proteins are largely unknown, but the proteins are implicated in signal transduction $(20,21)$, cell-cell interactions $(12,22,23)$, cell-extracellular matrix interactions (24), T-cell activation, and development $(4,11,25)$. These putative functions are consistent with a role in malignancy. The potential significance of KAIl as a metastasis suppressor gene was initially 
implicated in three human cancers; prostatic, non-small-cell lung, and pancreatic carcinomas. Advanced prostate tumors show decreased KAI1 expression relative to normal prostate and benign prostatic hyperplasia, and the down-regulation does not involve mutation or allelic loss of KAII (3). It has also been reported that both Gleason grade and clinical stage of prostate cancers have an inverse correlation to the percentage of KAI1-positive cancer cells (26). Higher Gleason grade prostate cancers or clinically advanced stages exhibit reduced levels of KAI1 expression. In non-small-cell lung cancers, the survival rate of patients with KAI1-postive cancer was significantly higher than the survival rate of patients with KAI1-negative cancer (27). Additionally, advanced pancreatic tumor stages, in which metastases are present, have reduced KAI1 mRNA levels relative to earlier pancreatic tumor stages (28). A recent study revealed that wildtype tumor suppressor $p 53$ can directly activate KAII/CD82 gene expression (29). On the contrary, immunohistochemical analysis of tumor tissue samples from prostate cancer patients showed that among p53-negative tumor samples, 39\% turned out to be KAI1/ CD82-positive, pointing to the possibility that KAI1/CD82 expression in cancer cells is regulated by other pathways in vivo (29). KAII has also been shown to be involved in non-small-cell lung cancer, bladder cancer, breast cancer, and gastric cancer (18, $27,28,30,31)$. So far, studies have focused mainly on epithelialderived tumors of adults. We now report the first study on KAII expression in the progression of two different pediatric tumors of neuroectodermal origin, EFT and NB.

EFT is a group of small-round-cell tumors that affects bone and soft tissues in children and young adults. EFT patients can be assigned to one of two different risk groups depending on the extent of the disease at diagnosis. Although approximately $60 \%$ of patients with localized disease can be cured by modern multimodal treatment regimens, patients with metastases are at an $80 \%$ risk of succumbing to the disease $(32,33)$. The genes responsible for metastasis in these tumors have not been well characterized. We have previously studied a candidate antimetastasis gene in EFT, $n m 23-H 1$ (34), but no correlation with prognosis or any pathophysiologic state could be established. NB is the most frequent solid tumor in children, forming approximately $8 \%$ of all pediatric tumors (35). The biologic diversity of neuroblastic tumors is vast and includes the phenomenon of complete, spontaneous regression (36) and maturation (37), even of disseminated tumors. In localized disease, regression processes are not only restricted to stage 1 or 2 disease, but may also, even if only rarely, be seen in patients with stage 3 disease (38). Besides these genetically and prognostically well-defined groups of NB (39), there are still some subsets of tumors for which further prognostic assessments would be needed. The purpose of this study was to investigate KAIl expression in EFT samples and in human NB for possible impact on prognosis.

\section{METHODS}

Tissue samples, cell lines, and culture conditions. The primary EFT tumors described in this report were diagnosed as Ewing's sarcoma or peripheral primitive neuroectodermal tumor according to the criteria of the Cooperative Ewing's Sarcoma Study (CESS). The presence of diagnostic EWS-ets gene fusions has been con- firmed in every case by routine RT-PCR. The frozen NB specimens used for the immunofluorescence were obtained from the collection in the Children's Cancer Research institute. The study was approved by the local institutional ethics committee, and informed consent was obtained from the parents.

Cell lines used were routinely maintained in RPMI 1640 (Invitrogen, Carlsbad, CA, U.S.A.) supplemented with $10 \%$ fetal bovine serum, penicillin $(0.1 \mathrm{mg} / \mathrm{mL})$, and streptomycin $(0.1$ $\mathrm{mg} / \mathrm{mL}$ ) in $5 \% \mathrm{CO}_{2}$ at $37^{\circ} \mathrm{C}$. The cell line SK-N-MC was a generous gift from Dr. J. Biedler (Memorial Sloan-Kettering Cancer Center, New York, NY, U.S.A.), WE-68, WE-M1-68, WE-M2-68, and VH64 were kindly provided by Dr. F. van Valen (Department of Pediatrics, University of Münster, Münster, Germany), TC-252 was a gift of Dr. T. Triche (Department of Pathology, Children's Hospital, Los Angeles, CA, U.S.A.), and A673, RDES, SK-ES1, LAN-1, and LAN-5 were obtained from the American Type Culture Collection (Rockville, MD, U.S.A.). Cell line IARC-EW2 was kindly supplied by Dr. G.M. Lenoir (International Agency for Research on Cancer, Lyon, France) and Vi856 by Otto Majdic (Institute for Immunology, Vienna, Austria). STA-ET-1, STA-ET-3, STA-ET-9, STA-ET-6, STA-ET-7, STA-ET-8, STA-NB-1, STA-NB-4, STA-NB-6, STA-NB-8, and STA-NB-10 are cell lines established in our institute.

RT-PCR and Northern blot analysis. First-strand cDNA synthesis was performed with $5 \mu \mathrm{g}$ of total RNA using random hexamer oligodeoxyribonucleotides (Pharmacia, Uppsala, Sweden) with standard procedures. On the basis of the nucleotide sequence of KAII/CD82 (9), 5'-AGTCCTCCCTGCTGCTGTGTG-3' was used as the sense primer and 5'-TCAGTCAGGGTGGGCAAGAGG-3' as the antisense primer to amplify a 1030-bp fragment representing the coding sequence of the KAII gene. Briefly, $5 \mu \mathrm{L}$ of cDNA was used for amplification with $0.2 \mathrm{U}$ DyNAzyme DNA polymerase (Finnzymes, Espoo, Finland) in 50 $\mathrm{mM} \mathrm{KCl}, 1.5 \mathrm{mM} \mathrm{MgCl}_{2}, 10 \mathrm{mM}$ Tris- $\mathrm{HCl}$ (pH 9.0), 0.1\% Triton $\mathrm{X}-100$, and $0.2 \mathrm{mM}$ of each of the four dNTPs in a $50-\mu \mathrm{L}$ final reaction volume. The reaction mixture was subjected to $30 \mathrm{PCR}$ amplification cycles of $40 \mathrm{~s}$ at $94^{\circ} \mathrm{C}, 60 \mathrm{~s}$ at $60^{\circ} \mathrm{C}$, and $60 \mathrm{~s}$ at $72^{\circ} \mathrm{C}$, preceded by a primary denaturation step of $10 \mathrm{~min}$ at $94^{\circ} \mathrm{C}$ and followed by a final extension step of $7 \mathrm{~min}$ at $72^{\circ} \mathrm{C}$ after the last cycle in a thermal cycler (Biometra, Göttingen, Germany). $\beta$-actin DNA amplification with the primers Act1, 5'-CTTCCTGGGCATGGAGCTC-3' and Act2, 5'-CGCTCAGGAGGAGCAATGAT-3', yielding a 210-bp product, was used as the internal PCR control under the same conditions. Water blanks were included routinely to control for possible DNA carryover and contamination. The amplified DNA samples were run on a $1 \%$ agarose gel, and bands were visualized with ethidium bromide and photographed. $p 53$ mutation was measured by PCR-SSCP analysis of genomic DNA and direct sequencing of affected genes (40).

For Northern analysis, $10 \mu \mathrm{g}$ of each RNA sample per lane, fractionated through a $1.2 \%$ agarose $/ 1.8 \mathrm{M}$ formaldehyde gel, was probed with a ${ }^{32} \mathrm{P}$-labeled full-length KAII cDNA. Quality and comparable loading of RNA samples were confirmed by including ethidium bromide in the gels and by rehybridizing blots to an 18S rDNA probe. After autoradiography, the filters were then exposed overnight to a Packard screen and scanned 
at 50- $\mu \mathrm{m}$ resolution in a phosphorimager instrument for quantification (Cyclone Instrument; Packard, Meriden, CT, U.S.A.).

Immunoblot analysis. The Western blot protocol was essentially based on previously reported methods with some modifications (10). Briefly, cell monolayers were homogenized with extraction/lysis buffer [10 mM Tris- $\mathrm{HCl}(\mathrm{pH} 8.0), 150 \mathrm{mM} \mathrm{NaCl}, 3$ $\mathrm{mM} \mathrm{MgCl} 2,0.5 \% \mathrm{NP} 40,2 \mathrm{mM}$ phenylmethylsulfonyl fluoride, 1 $\mu \mathrm{g} / \mathrm{mL}$ leupeptin, and $1 \mu \mathrm{g} / \mathrm{mL}$ aprotinin] after centrifugation at $4^{\circ} \mathrm{C}$ for $5 \mathrm{~min}$ at $1200 \mathrm{rpm}$. The lysates were then centrifuged at $14,000 \mathrm{rpm}$ at $4^{\circ} \mathrm{C}$ for $10 \mathrm{~min}$. Approximately $20 \mu \mathrm{g}$ of cellular protein was size fractionated by $10 \%$ SDS-PAGE, and Western blots were incubated with anti-KAI1 C33 hybridoma supernatant (10) at 1:100 dilution. To ensure equal loading of protein, control experiments were performed with an actin MAb (ICN Biomedicals, Inc. Aurora, OH, U.S.A.).

Immunohistology. KAI1 expression was analyzed on frozen tissue sections of 30 neuroblastic tumor specimens with different genetic make-ups by immunohistology. Stroma-poor areas were investigated from 26 tumors and ganglioneuromatous areas from four tumors. In two cases, lymph node metastases were investigated and not primary tumor material. Twenty-seven tumor specimens were obtained at the time of diagnosis, three after administration of cytotoxic therapy. Briefly, 6- $\mu \mathrm{m}$ frozen sections were fixed with $4 \%$ paraformaldehyde (Merck, Darmstadt, Germany) for $10 \mathrm{~min}$ at $4^{\circ} \mathrm{C}$ and air-dried. After a washing step, fixed sections were incubated with a mouse anti-KAI1 C33 MAb at a dilution of 1:100 for $1 \mathrm{~h}$. Visualization of bound antibodies was performed by using an FITC-labeled rabbit anti-mouse antibody. Nuclei were counterstained with 4'-6-diamidino-2-phenylindole$2 \mathrm{HCl}$ (DAPI). The staining pattern of the KAI1 protein in the neuroblastic tumors was judged independently by two observers blind to the KAII mRNA/protein data.

\section{RESULTS}

KAI1 mRNA expression in EFT and NB cells. We initially examined whether KAII mRNA expression varied among the various EFT and NB tumor samples by analyzing respective cell

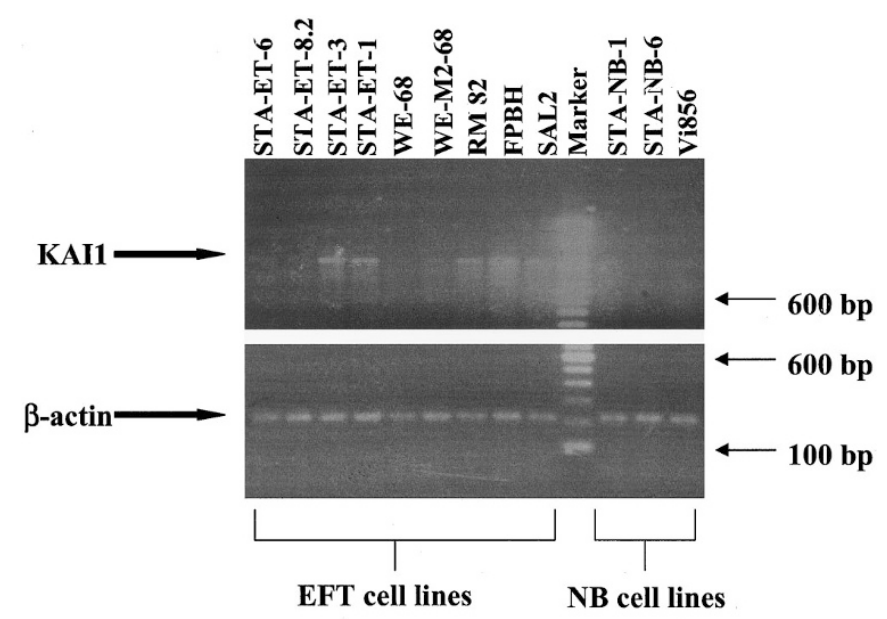

Figure 1. Representative photographs from ethidium bromide-stained gel of RT-PCR-amplified 1031-bp KAII cDNA and 210-bp $\beta$-actin cDNA. EFT cell lines, NB cell lines, and size marker are indicated for both $K A I 1$ and $\beta$-actin PCR-amplified products. lines using RT-PCR. KAII transcript levels were detected in 24 of 29 EFT and zero of eight NB cell lines examined. Figure 1 shows variable levels of KAIl mRNA expression in a representative series of EFT cell lines derived from different tumor stages at diagnosis (Table 1). NB cell lines established from primary tumors representing different stages of the disease showed either very weak or no measurable KAII mRNA expression (Fig. 1). RT-PCR analysis also showed variably weak or absent levels of KAIl mRNA in primary EFT samples analyzed (in comparison to lymphocytes) irrespective of the metastatic status at diagnosis. Also, a heterogenous expression pattern among the different tumor samples was observed with most tumors showing undetectable or relatively faint KAII mRNA expression (data not shown). No correlation of KAII expression to the metastasis state in the primary tumors could be found.

To further evaluate the expression of KAII message in several EFT and NB cell lines, we also performed Northern blot analyses using a full-length KAIl cDNA fragment as a probe. Steady-state transcript levels of $K A I 1$ was quantified by phosphorimager analysis and normalized by comparison with the hybridization signal obtained with an $18 \mathrm{~S}$ rDNA probe. A summary of the results is provided in Table 1. Although there were some differences in the level of expression among those

Table 1. p53 status and KAII mRNA levels in EFT cell lines

\begin{tabular}{lclcc}
\hline \multicolumn{1}{c}{ Cell line } & Fusion type* & \multicolumn{1}{c}{ Origin } & $p 53$ Status & $\begin{array}{c}\text { KAII } \\
\text { Expression† }\end{array}$ \\
\hline STA-ET-1 & $(7 / 6) 1$ & Relapse & wt & 1.8 \\
STA-ET-2.1 & $(9 / 4)$ & $1^{\circ}$ tumor & mut & 1 \\
STA-ET-2.2 & $(9 / 4)$ & Metastasis & mut & 1.2 \\
STA-ET-3 & $(7 / 6) 1$ & Metastasis & wt & 1.8 \\
STA-ET-4 & $(7 / 6) 1$ & $1^{\circ}$ tumor & nd & 1.6 \\
STA-ET-5 & n.d. & $1^{\circ}$ tumor & nd & 0.8 \\
STA-ET-6 & $(7 / 6) 1$ & Pleural effus. & wt & 1.2 \\
STA-ET-7.1 & $(7 / 5) 2$ & $1^{\circ}$ tumor & mut & 0.8 \\
STA-ET-7.2 & $(7 / 5) 2$ & Pleural effus. & mut & 1.2 \\
STA-ET-7.3 & $(7 / 5) 2$ & Metastasis & mut & 1.4 \\
STA-ET-8.1 & $(7 / 5) 2$ & $1^{\circ}$ tumor & mut & 1 \\
STA-ET-8.2 & $(7 / 5) 2$ & Pleural effus. & nd & 0.9 \\
STA-ET-9 & $(7 / 6) 2$ & $1^{\circ}$ tumor & wt & 1.2 \\
STA-ET-10 & FEV & $1^{\circ}$ tumor & wt & 1.6 \\
STA-ET-11 & ERG & $1^{\circ}$ tumor & wt & 1.6 \\
STA-ET-12 & $(7 / 5) 2$ & $1^{\circ}$ tumor & wt & nd \\
SAL1 & $(7 / 6) 1$ & $1^{\circ}$ tumor & wt & nd \\
SAL2 & $(7 / 6) 1$ & Relapse & wt & nd \\
A673 & $(7 / 6) 1$ & nd & mut & 1.6 \\
RDES & $(7 / 5) 2$ & $1^{\circ}$ tumor & mut & 1.8 \\
EW2(D) & $(7 / 5) 2$ & Blood & mut & 1.4 \\
TC252 & $(7 / 6) 1$ & Metastasis & wt & 1 \\
VH64 & $(7 / 5) 2$ & Metastasis & wt & 1 \\
SK-N-MC & $(7 / 6) 1$ & Metastasis & mut & 1.2 \\
SK-ES1 & $(7 / 5) 2$ & $1^{\circ}$ tumor & mut & 0.8 \\
WE 68 & $(7 / 6) 1$ & $1^{\circ}$ tumor & wt & 1 \\
WE-M1-68 & $(7 / 6) 1$ & Metastasis $^{2} 1$ & wt & 1 \\
WE-M2-68 & $(7 / 6) 1$ & Metastasis & wt & 1.2 \\
RM82 & ERG & $1^{\circ}$ tumor & mut & 1.4 \\
\hline
\end{tabular}

* (7/6) 1, EWS exon 7 and FLI1 exon 6 fusion, type 1; (7/5) 2, EWS exon 7 and FLI1 exon 6 fusion, type 2; (FEV), EWS and FEV fusion; (ERG), EWS and ERG fusion.

$\dagger$ Relative KAI1 expression data, normalized to 18S rDNA control, obtained by phosphorimager analysis of Northern blots.

Abbreviations used: wt, wild type; mut, mutation; nd, not determined; $1^{\circ}$ tumor, primary tumor; Pleural effus., pleural effusion. 
cell lines studied, we observed KAII mRNA of about $2.4 \mathrm{~kb}$ in most of the EFT cell lines (Fig. 2) but no or relatively weak $K A I I$ transcript was detected in the NB cell lines studied (Fig. 2 ). The variability in the KAII mRNA expression levels could not be correlated with the $p 53$ mutation status in all the EFT cell lines (Table1). The Northern data corroborated the RTPCR results.

KAI1 protein levels in EFT and NB cell lines. To confirm the expression of KAIl gene at the protein level, all the EFT and NB cell lines studied for mRNA expression were also examined for their KAI1 protein content by immunoblot analysis. KAI1 protein from the EFT cell lines migrated between $M_{\mathrm{r}} 30,000$ and $M_{\mathrm{r}} 60,000$ and appeared as smear owing to the presence of glycosylation variants of different molecular weights (Fig. 3). No KAI1 expression was observed in the NB cell lines analyzed (Fig. 3) in concordance with the mRNA data. The level of KAI1 protein in two EFT cell lines, STAET-1 and STA-ET-3, was comparable to that in the MOLT-4 cell line, which has been reported to express high levels of KAI1 protein (10). KAI1 expression size in the MOLT-4 cell line, which served as the positive control, varied from $M_{\mathrm{r}}$ 30,000 to more than $M_{\mathrm{r}} 66,000$ in molecular weight, whereas no expression was observed in the NIH $3 \mathrm{~T} 3$ cell line, which served as our negative control (Fig. 3). The glycosylation pattern among the different EFT cell lines varied considerably, with some showing discrete bands, instead of the normal smear, higher than $28 \mathrm{kD}$, which is the size of the predicted molecular weight of KAI1 on the basis of its amino acid sequence (9). A representative Western blot for actin protein (Fig. 3, bottom) showed consistent loading of protein from the different cell lines. We also investigated the relationship of KAI1 expression and another TM4SF protein, CD81 (TAPA 1) in some of the cell lines. We observed that although KAI1 showed heterogenous expression, CD81 was homogeneously expressed in the cell lines analyzed (data not shown). KAI1 protein expression as examined by Western blot analysis was also consistent with KAII RNA expression as measured by RT-PCR analysis in all cell lines studied with the exception of
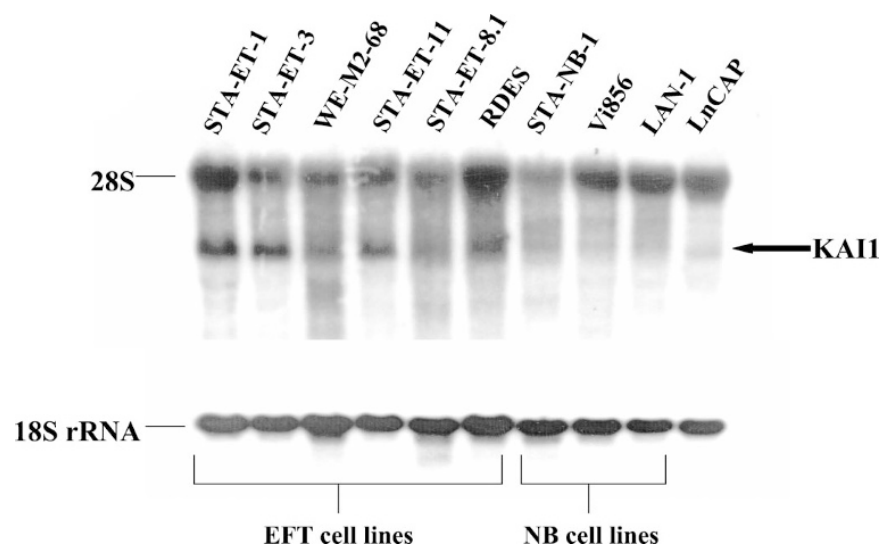

Figure 2. Representative Northern blot analysis of KAII mRNA expression in various EFT and NB cell lines. Although variable expression levels were observed in the EFT cell lines, no KAIl transcript was detectable in the NB cell lines, and $K A I 1$ probe cross-reacted with $28 \mathrm{~s}$. The filters were rehybridized to an $18 \mathrm{~S}$ rDNA probe to check quality and loading of RNA.

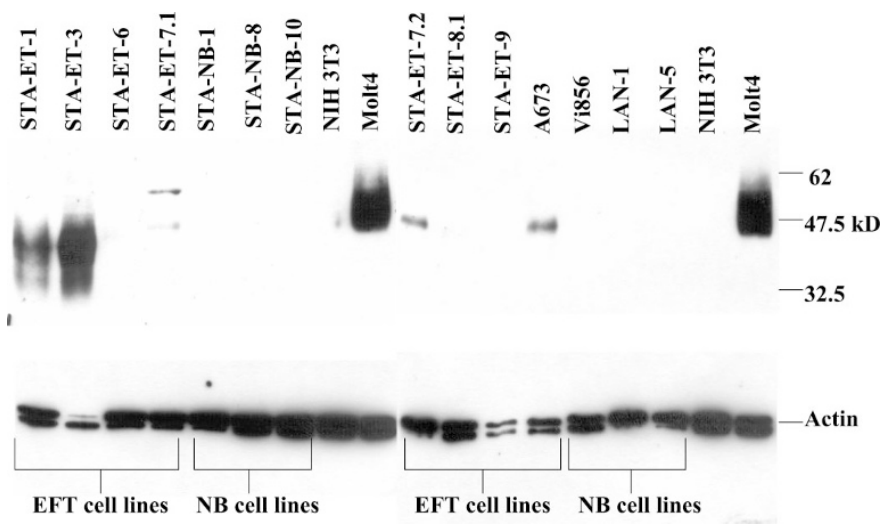

Figure 3. Western blot analysis of KAI1 expression in representative EFT and NB cell lines as well as a positive (MOLT-4) and a negative (NIH 3T3) control cell lines. Protein cell lysates were prepared from cell lines, sizefractionated by SDS-PAGE, transferred to nitrocellulose membranes, incubated with anti-KAI1 C33 or actin antibodies, and exposed to film. Size markers in $\mathrm{kD}$ are noted.

the STA-ET-6 cell line in which, although considerable level of mRNA was expressed, no protein was detected.

KAII expression does not correlate with any genetic markers of NB tumors. Inasmuch as $K A I 1$ expression was relatively undetectable in all the NB cell lines analyzed, we decided to check for possible expression in primary NB tumor samples by immunofluorescence analysis. Twenty of the 30 tumor specimens analyzed did not show any reaction with the KAII C33 antibody (Fig. 4A, Table 2). Ganglioneuromatous areas showed either no reaction (two cases, Fig. $4 B$ ) or positive reactions in differentiating cells (one case) and some ganglionic-like cells (one case after therapy). Stroma-poor areas of eight tumors showed either a weak positivity in single areas (two cases) or a weak to moderate positivity in the majority of the tumor cells (six cases, Fig. 4, $C$ and $D$, one after therapy). Lymphocytes always showed strong reactions, unequivocally exceeding the positivity found in the tumor cells (Fig. 4, $A, E$, and $F$ ) and so served as our internal positive control. No correlation was found between KAII expression and genetic markers of the tumor, such as $M Y C N$ amplification/gain, chromosome 1p36.3 deletions/imbalances (Table 2) or gains of the long arm of chromosome 17 (data not shown).

\section{DISCUSSION}

Among all genetic aberrations, inactivation of metastasis suppressor genes is one important factor contributing to the formation of tumor metastasis. KAII expression has previously been demonstrated to inversely correlate with the metastatic potential and consequently with prognosis of several epithelial neoplasms in adults. This is the first report evaluating KAII expression in pediatric tumors. We have focused on two neuroectodermal neoplasms, NB and EFT. Although no or very low level expression of KAII was generally observed in NB, variable but, when compared with bone marrow cells, mostly low positivity was observed in EFT. The most comprehensive KAIl analysis was performed on cell lines. Although two EFT cell lines showed KAI1 protein levels comparable to that of MOLT-4, the overall results obtained were in line with those of 

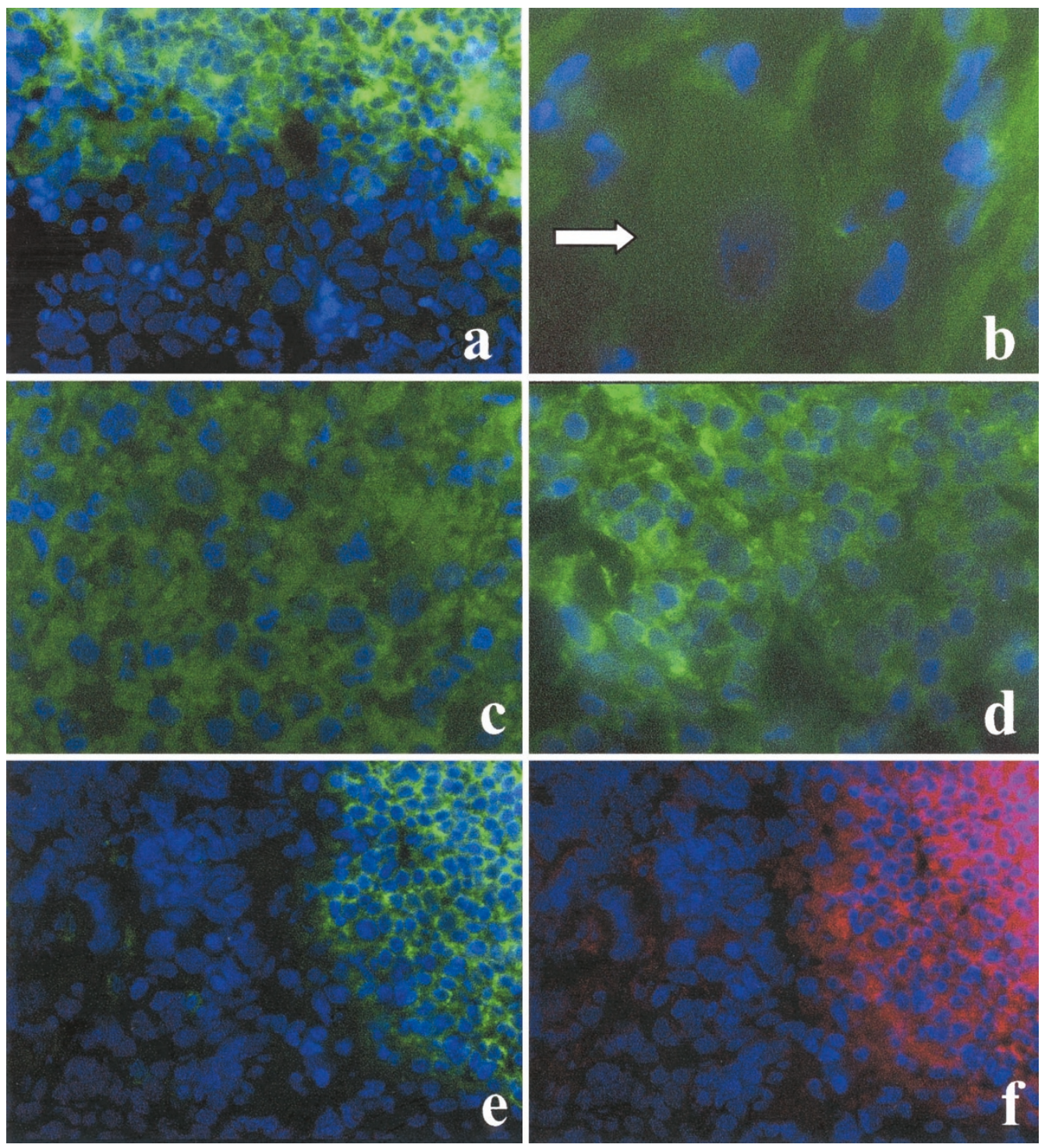

Figure 4. Immunofluorescence detection of $K A I 1$ in samples from patients with different stages of NB. Frozen sections were incubated with the C33 MAb. $A$, KAIl-negative tumor cells (blue) surrounded by KAII-positive lymphocytes (green). B, ganglioneuromatous tissue with KAII-negative neoplastic ganglionic cells. Arrow points to a ganglionic cell. $C$, stroma-poor NB with a weak $K A I 1$ positivity. $D$, stroma-poor NB with a weak to moderate $K A I 1$ expression. $E$ and $F$, lymphatic tissue was used as an internal positive control (double staining was performed with a CD45 antibody and an FITC-conjugated secondary antibody, shown in $E$, and KAI1 highlighted with a TRITC-conjugated secondary antibody, given in F). Magnification $A$, $C, D=\times 375 ; B=\times 750$.

White et al. (19), who analyzed KAI1 protein in normal and cancer cells of a variety of tissues and observed that KAI1 protein was specifically down-regulated in most of the cancer cell lines analyzed. Cell lines may in fact represent a group of patients with bad prognosis because establishment of in vitro cell cultures has been shown to select for secondary genetic aberrations, including p53 mutations and INK4A deletions in EFT (41), and disruption of $p 53$ function has been correlated with KAI1 deficiency in some malignancies, including prostate tumors (29). In our study, however, RT-PCR analysis of a small number of primary EFT and immunohistologic analysis of a series of primary NB corroborated the cell line results giving no indication of a stage-dependent expression of KAI1 in these tumors. Also, for EFT no correlation with the $p 53$ status was seen. In addition, using an EFT cell line carrying a conditional p53 mutant (p53val138) no changes in KAI1 ex- pression were noted on $p 53$ induction (data not shown). Thus we were unable to confirm a correlation between KAIl expression and $p 53$ status as has been controversially discussed in the literature before (42). In our series, low KAII expression was already detected on the RNA level. Although we have not tested for the genomic status of the KAII gene in NB and EFT, evidence so far obtained from other tumors with reduced or absent KAII expression suggests that neither loss of heterozygosity at the KAII locus $(43,44)$ nor the presence of mutations within the $K A I I$ gene $(3,45,46)$ nor hypermethylation of a CpG island within the KAII promoter (42) appears likely to be responsible. The presence of an extra-large intron 1 and noncoding exons at the 5'-region of the KAII gene suggests that the regulation of KAII gene expression may not be simple (47).

EFT are characterized by expression of an EWS-ets gene rearrangement of variable architecture. For localized disease 
Table 2. Summary of NB patients characteristics and KAI1 expression

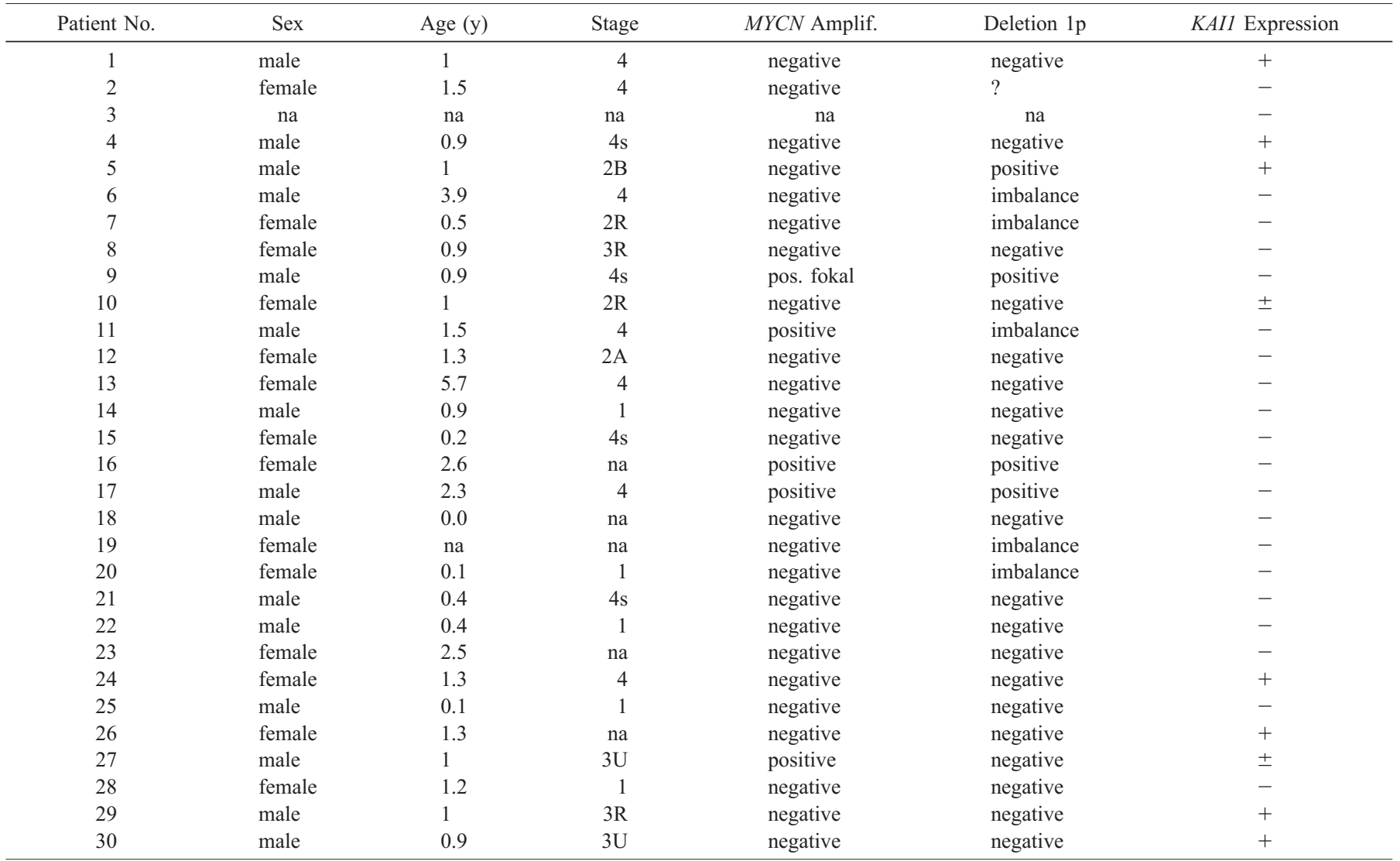

Abbreviations used: - , no expression; \pm , weak positivity in single cells; + , weak to moderate positivity; na, not available.

the two main fusion types EWS-FLI1 type 1 and type 2 appear to be associated with distinct clinical outcomes $(48-51)$. In addition, patients who present with clinically overt metastatic disease at diagnosis generally have an adverse prognosis. In our series of EFT cell lines and primary tumors, variation in KAII expression correlated neither with EWS-FLII fusion type nor with the stage of the disease at which the tumor material was collected. It should be noted, however, that in primary EFT, KAIl expression, if present, was low. Because in the prechemotherapy era, when EFT were treated solely by surgery and irradiation, most patients succumbed to distant relapse, EFT may be envisaged as a generally metastasizing disease. Low KAI1 expression may therefore reflect a common metastatic potential in this disease. Our results are generally in concordance with KAI1 studies on bone and soft tissue tumors in which no correlation was found between metastasis of osteosarcoma cells to the lungs and loss of KAI1/CD82 (52).

By contrast, the spectrum of NB presentation reaches from highly aggressive metastasizing disease to a spontaneously regressing or maturing localized tumor. Several genetic traits are considered to be associated with distinct clinical outcome in NB, including ploidy, $M Y C N$ amplification, chromosome 1 p36 deletions or imbalances, and gain of chromosome 17q. Our series of NB tumors comprised representative material from all disease stages and different genetic make-ups (Table 2). However, KAII expression was found to be uniformly absent or very weak to moderate in 20 and 10 of 30 tumors, respectively, with no correlation to the extent of the disease, any genetic trait, or clinical outcome.

In summary, our data indicate that in contrast to a growing list of cancers in which down-regulation of KAII is associated with tumor progression, KAII expression cannot serve as a prognostically useful marker in NB and EFT. However, these results do not exclude a role for KAII down-regulation in the biology of the disease. Also, our results clearly revealed a difference in the KAII expression patterns between EFT and NB that may reflect differences in either the specific tumor biology or origin. Analysis of other pediatric malignancies of neuroectodermal and nonneuroectodermal histogenesis will contribute to a more general understanding of the role KAI1 may play in children's cancer.

Acknowledgments. The authors thank Dr. Eva Stefani for NB patients' information and Dr. Freimuth Schilling (Olga Hospital, Stuttgart, Germany) for kindly providing tumor samples. We appreciate the kindness of Drs. J. Carl Barrett and Julie Foley (NIEHS, Research Triangle Park, NC, U.S.A.) for helpful suggestions to the study.

\section{REFERENCES}

1. Kohn EC 1993 Development and prevention of metastasis. Anticancer Res 13:25532559

2. Dear TN, Kefford RF 1990 Molecular oncogenetics of metastasis. Mol Aspects Med 11:243-324

3. Dong JT, Suzuki H, Pin SS, Bova GS, Schalken JA, Isaacs WB, Barrett JC, Isaacs JT 1996 Down-regulation of the KAII metastasis suppressor gene during the progression 
of human prostatic cancer infrequently involves gene mutation or allelic loss. Cancer Res 56:4387-4390

4. Gaugitsch HW, Hofer E, Huber NE, Schnabl E, Baumruker T 1991 A new superfamily of lymphoid and melanoma cell proteins with extensive homology to Schistosoma mansoni antigen Sm23. Eur J Immunol 21:377-383

5. Maecker HT, Todd SC, Levy S 1997 The tetraspanin superfamily: molecular facilitators. FASEB J 11:428-442

6. Engel P, Tedder TF 1994 New CD from the B cell section of the Fifth International Workshop on Human Leukocyte Differentiation Antigens. Leuk Lymphoma 13:61-64

7. Ikeyama S, Koyama M, Yamaoko M, Sasada R, Miyake M 1993 Suppression of cell motility and metastasis by transfection with human motility-related protein (MRP-1/ CD9) DNA. J Exp Med 177:1231-1237

8. Kondoh M, Ueda M, Ichihashi M, Mishima Y 1993 Decreased expression of human melanoma-associated antigen ME491 along the progression of melanoma precanceroses to invasive and metastatic melanomas. Melanoma Res 3:241-245

9. Dong JT, Lamb PW, Rinker-Schaeffer CW, Vukanovic J, Ichikawa T, Isaacs JT, Barrett JC $1995 \mathrm{KAIl}$, a metastasis suppressor gene for prostate cancer on human chromosome 11p11.2. Science 268:884-886

10. Fukudome K, Furuse M, Imai T, Nishimura M, Takagi S, Hinuma Y, Yoshie O 1992 Identification of membrane antigen $\mathrm{C} 33$ recognized by monoclonal antibodies inhibitory to human T-cell leukemia virus type 1 (HTLV-1)-induced syncytium formation: altered glycosylation of C33 antigen in HTLV-1-positive T cells. J Virol 66:13941401

11. Lebel-Binay S, Gil ML, Lagaudriere C, Miloux B, Marchiol-Fournigault C, QuilletMary A, Lopez M, Fradelizi D, Conjeaud H 1994 Further characterization of CD82/IA4 antigen (type III surface protein): an activation/differentiation marker of mononuclear cells. Cell Immunol 154:468-483

12. Nojima Y, Hirose T, Tachibana K, Tanaka T, Shi L, Doshen J, Freeman GJ, Schlossman SF, Morimoto C 1993 The 4F9 antigen is a member of the tetra spans transmembrane protein family and functions as an accessory molecule in $\mathrm{T}$ cell activation and adhesion. Cell Immunol 152:249-260

13. Mannion BA, Berditchevski F, Kraeft SK, Chen LB, Hemler ME 1996 Transmembrane-4 superfamily proteins CD81 (TAPA-1), CD82, CD63, and CD53 specifically associated with integrin alpha 4 beta 1 (CD49d/CD29). J Immunol 157:2039-2047

14. Rubinstein E, Le Naour F, Lagaudriere-Gesbert C, Billard M, Conjeaud H, Boucheix C 1996 CD9, CD63, CD81, and CD82 are components of a surface tetraspan network connected to HLA-DR and VLA integrins. Eur J Immunol 26:2657-2665

15. Afshari CA, Nuwaysir EF, Barrett JC 1999 Application of complementary DNA microarray technology to carcinogen identification, toxicology, and drug safety evaluation. Cancer Res 59:4759-4760

16. Hemler ME, Mannion BA, Berditchevski F 1996 Association of TM4SF proteins with integrins: relevance to cancer. Biochim Biophys Acta 1287:67-71

17. Radford KJ, Thorne RF, Hersey P 1996 CD63 associates with transmembrane 4 superfamily members, CD9 and CD81, and with beta 1 integrins in human melanoma. Biochem Biophys Res Commun 222:13-18

18. Huang CI, Kohno N, Ogawa E, Adachi M, Taki T, Miyake M 1998 Correlation of reduction in MRP-1/CD9 and KAI1/CD82 expression with recurrences in breast cancer patients. Am J Pathol 153:973-983

19. White A, Lamb PW, Barrett JC 1998 Frequent downregulation of the KAI1(CD82) metastasis suppressor protein in human cancer cell lines. Oncogene 16:3143-3149

20. Bell GM, Bolen JB, Imboden JB 1992 Association of Src-like protein tyrosine kinases with the CD2 cell surface molecule in rat T lymphocytes and natural killer cells. Mol Cell Biol 12:5548-5554

21. Gil ML, Vita N, Lebel-Binay S, Miloux B, Chalon P, Kaghad M, MarchiolFournigault C, Conjeaud H, Caput D, Ferrara P 1992 A member of the tetra spans transmembrane protein superfamily is recognized by a monoclonal antibody raised against an HLA class I-deficient, lymphokine-activated killer-susceptible, B lymphocyte line: cloning and preliminary functional studies. J Immunol 148:2826-2833

22. Hadjiargyrou M, Patterson PH 1995 An anti-CD9 monoclonal antibody promotes adhesion and induces proliferation of Schwann cells in vitro. J Neurosci 15:574-583

23. Masellis-Smith A, Shaw AR 1994 CD9-regulated adhesion: anti-CD9 monoclonal antibody induce pre-B cell adhesion to bone marrow fibroblasts through de novo recognition of fibronectin. J Immunol 152:2768-2777

24. Anton ES, Hadjiargyrou M, Patterson PH, Matthew WD 1995 CD9 plays a role in Schwann cell migration in vitro. J Neurosci 15:584-595

25. Boismenu R, Rhein M, Fischer WH, Havran WL 1996 A role for CD81 in early T cell development. Science 271:198-200

26. Ueda T, Ichikawa T, Tamaru J, Mikata A, Akakura K, Akimoto S, Imai T, Yoshie O, Shiraishi T, Yatani R, Ito H, Shimazaki J 1996 Expression of the KAI1 protein in benign prostatic hyperplasia and prostate cancer. Am J Pathol 149:1435-1440

27. Adachi M, Taki T, Ieki Y, Huang CL, Higashiyama M, Miyake M 1996 Correlation of $K A I 1 / C D 82$ gene expression with good prognosis in patients with non-small cell lung cancer. Cancer Res 56:1751-1755

28. Guo X, Friess H, Graber HU, Kashiwagi M, Zimmermann A, Korc M, Buchler MW 1996 KAII expression is up-regulated in early pancreatic cancer and decreased in the presence of metastases. Cancer Res 56:4876-4880
29. Mashimo T, Watabe M, Hirota S, Hosobe S, Miura K, Tegtmeyer PJ, Rinker-Shaeffer CW, Watabe K 1998 The expression of the KAII gene, a tumor metastasis suppressor, is directly activated by p53. Proc Natl Acad Sci USA 95:1307-11311

30. Yu Y, Yang JL, Markovic B, Jackson P, Yardley G, Barrett J, Russell PJ 1997 Loss of KAI1 messenger RNA expression in both high-grade and invasive human bladder cancers. Clin Cancer Res 3:1045-1049

31. Hinoda Y, Adachi Y, Takaoka A, Mitsuuchi H, Satoh Y, Itoh F, Kondoh Y, Imai K 1998 Decreased expression of the metastasis suppressor gene $K A I 1$ in gastric cancer. Cancer Lett 129:229-234

32. Kovar H 1998 Progress in the molecular biology of Ewing tumors. Sarcoma 2:3-17

33. Paulussen M, Ahrens S, Dunst J, Winkelmann W, Exner GU, Kotz R, Amann G, Dockhorn-Dworniczak B, Harms D, Muller-Weihrich S, Welte K, Kornhuber B, Janka-Schaub G, Gobel U, Treuner J, Voute PA, Zoubek A, Gadner H, Jurgens H 2001 Localized Ewing tumor of bone: final results of the Cooperative Ewing's Sarcoma Study CESS 86. J Clin Oncol 19:1818-1829

34. Aryee DN, Strobel T, Kos K, Salzer-Kuntschik M, Zoubek A, Veron M, Ambros IM, Traincart F, Gadner H, Kovar H 1995 High nm23-H1/NDPK-A expression in Ewing tumors: paradoxical immunohistochemical reactivity and lack of prognostic significance. Int J Cancer 64:104-111

35. Brodeur GM, Sekhon G, Goldstein MN 1977 Chromosomal aberrations in human neuroblastomas. Cancer 40:2256-2263

36. Ambros PF, Brodeur GM 2000 Concept of tumorigenesis and regression In: Brodeur GM, Sawada T, Tsuchida Y, Voute PA (eds) Neuroblastoma. Elsevier, Amsterdam, pp 21-32

37. Ambros IM, Ambros PF 2000 The role of Schwann cells in neuroblastoma In: Brodeur GM, Sawada T, Tsuchida Y, Voute PA (eds) Neuroblastoma. Elsevier, Amsterdam, pp 229-243

38. Yamamoto K, Hanada R, Kikuchi A, Ichikawa M, Aihara T, Oguma E, Moritani T, Shimanuki Y, Tanimura M, Hayashi Y 1998 Spontaneous regression of localized neuroblastoma detected by mass screening. J Clin Oncol 16:1265-1269

39. Brodeur GM, Ambros PF 2000 Genetic and biological markers of prognosis in neuroblastoma In: Brodeur GM, Sawada T, Tsuchida Y, Voute PA (eds) Neuroblastoma. Elsevier, Amsterdam, pp 355-369

40. Kovar H, Auinger A, Jug G, Aryee D, Zoubek A, Salzer-Kuntschik M, Gadner H 1993 Narrow spectrum of infrequent p53 mutations and absence of MDM2 amplification in Ewing tumours. Oncogene 8:2683-2690

41. Kovar H, Jug G, Aryee DNT, Zoubek A, Ambros P, Gruber B, Windhager R, Gadner H 1997 Among genes involved in the RB dependent cell cycle regulatory cascade, the p16 tumor suppressor gene is frequently lost in the Ewing family of tumors. Oncogene 15:2225-2232

42. Jackson P, Puisieux A 2000 Is the $K A I 1$ metastasis suppressor gene a cellular target of p53? A review of current evidence. Biochem Biophys Res Commun 278:499-502

43. Kawana Y, Komiya A, Ueda T, Nihei N, Kuramochi H, Suzuki H, Yatani R, Imai T, Dong JT, Yoshie O, Barrett JC, Isaacs JT, Shimazaki J, Ito H, Ichikawa T 1997 Location of KAII on the short arm of human chromosome 11 and frequency of allelic loss in advanced human prostate cancer. Prostate 32:205-213

44. Tagawa K, Arihiro K, Takeshima Y, Hiyama E, Yamasaki M, Inai K 1999 Downregulation of KAI1 messenger RNA expression is not associated with loss of heterozygosity of the KAII gene region in lung adenocarcinoma. Jpn J Cancer Res 90:970-976

45. Miyazaki T, Kato H, Shitara Y, Yoshikawa M, Tajima K, Masuda N, Shouji H, Tsukada K, Nakajima T, Kuwano H 2000 Mutation and expression of the metastasis suppressor gene $K A I I$ in esophageal squamous cell carcinoma. Cancer 89:955-962

46. Ow K, Delprado W, Fisher R, Barrett J, Yu Y, Jackson P, Russell PJ 2000 Relationship between expression of the KAII metastasis suppressor and other markers of advanced bladder cancer. J Pathol 191:39-47

47. Dong JT, Isaacs WB, Barrett JC, Isaacs JT 1997 Genomic organization of the human KAIl metastasis-suppressor gene. Genomics 41:25-32

48. Zoubek A, Dockhorn Dworniczak B, Delattre O, Christiansen H, Niggli F, Gatterer Menz I, Smith TL, Jurgens H, Gadner H, Kovar H 1996 Does expression of different EWS chimeric transcripts define clinically distinct risk groups of Ewing tumor patients? J Clin Oncol 14:1245-1251

49. De-Alava E, Kawai A, Healey JH, Fligman I, Meyers P, Huvos AG, Gerald WL, Jhanwar SC, Argani P, Antonescu CR, Pardo-Mindan FJ, Ginsberg J, Womer R, Lawlor ER, Wunder J, Andrulis I, Sorensen PHB, Barr FG, Ladanyi M 1998 EWS-FLI1 fusion transcript structure is an independent determinant of prognosis in Ewings sarcoma. J Clin Oncol 16:1248-1255

50. Amann G, Zoubek A, Salzer-Kuntschik M, Windhager R, Kovar H 1999 Relation of neurological marker expression and EWS gene fusion types in MIC2/CD99-positive tumors of the Ewing family. Hum Pathol 30:1058-1064

51. Aryee DN, Sommergruber W, Muehlbacher K, Dockhorn-Dworniczak B, Zoubek A, Kovar H 2000 Variability in gene expression patterns of Ewing tumor cell lines differing in EWS-FLI1 fusion type. Lab Invest 80:1833-1844

52. Arihiro K, Inai K 2001 Loss of KAI1/CD82 expression in bone and soft tissue tumors is not associated with lung metastasis. Pathol Res Pract 197:627-633 